\title{
In Memoriam Jacques Tixier (1925-2018)
}

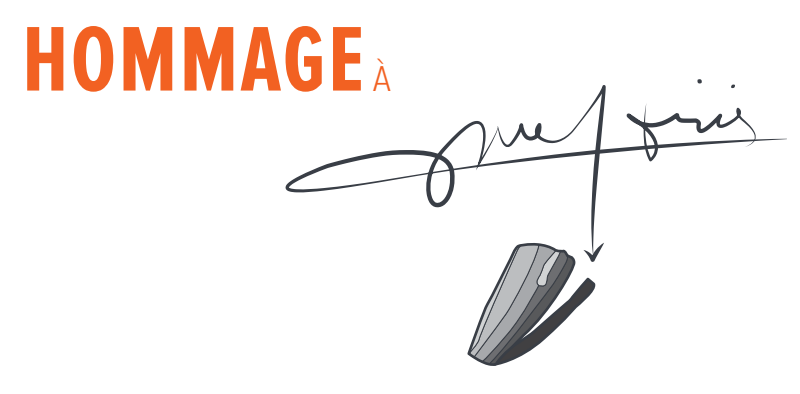

\author{
Foni Le Brun-Ricalens ${ }^{1}$, Yann Potin ${ }^{2}$
}

Keywords

Kulcsszavak

Authors • Szerzők

Cite as • hivatkozás

Article history • Kézirat történet

Copyright • Jogok (c) (i) $(5)$
Jacques Tixier, in memoriam, prehistory, stone tools, lithic technology, bibliography Jacques Tixier, megemlékezés, ôstörténet, köeszközök, kôtechnológia, szakirodalom

1 - chargé de direction, Centre national de Recherche Archéologique, Conservateur du service d'archéologie préhistorique, Musée National d'Histoire et d'Art, Membre permanent de l'Union Internationale des Sciences Pré- et Protohistoriques. 241, rue de Luxembourg L-8077 Bertrange Luxembourg; e-mail: foni.lebrun@cnra.etat. lu

2 - chargé d'études documentaires Archives nationales, Département Education, Culture et Affaires sociales Maître de conférences associé en Histoire du droit. Université Paris-Nord. 59, rue Guynemer F-93383 Pierrefittesur-Seine France e-mail : yann.potin@culture.gouv.fr

Le Brun-Ricalens, F., Potin, Y. (2018) In Memoriam Jacques Tixier (1925-2018) Litikum 6: 5-12. https://doi.org/10.23898/litikuma0021

Received | Érkezés: 2018. 08. 21. Accepted | Elfogadás: 2018. 09. 21. Published | Közzététel: 2018. 11. 30.

(C) 2018 Le Brun-Ricalens, Potin. This is an open-access article distributed under the terms of the Creative Commons Attribution License, which permits unrestricted use, distribution, and reproduction in any medium, provided the original author and source are credited. | Ez egy nyílt hozzáférésű publikáció, amit a Creative Commons 4.0 licensze véd. A termék szabadon használható, terjeszthető és sokszorosítható az eredeti szerző és forrás megjelölése mellett.

\section{Grand préhistorien et ethnologue des techniques}

L'archéologue et technologue français Jacques Tixier s'est éteint le 3 avril 2018 à l'âge de 93 ans dans sa demeure de Pradines (Lot, France). Disparaît avec lui la génération des pionniers qui ont fait de la préhistoire française une science au rayonnement international, contribuant à ce que cette jeune science soit considérée comme telle, à part entière.

\section{Un précurseur des recherches en technologie lithique}

La préhistoire étant une science à la fois expérimentale et spéculative, Jacques Tixier eu l'intuition, l'énergie et la rigueur pour investir et s'investir dans cet espace stratégique qu'est la délicate interface partagée par les sciences humaines et les sciences de la nature. Il revient à ce chercheur passionné et exigeant d'avoir osé aborder ce terrain d'étude en initiant une nouvelle méthode d'investigation pour contribuer à la compréhension des comportements humains au cours des temps préhistoriques. En ethno-technologue, Jacques Tixier propose d'étudier certaines relations dialectiques du rapport Nature - Culture, en particulier celles qui concernent

\section{A great prehistorian and technology ethnologist}

Jacques Tixier, an archaeologist and technologist, passed away at the age of 93 on 3 April 2018 in his home at Pradines (France) near the Lot river and chalk cliffs which he loved to watch as they glowed in the evening sun in springtime. His death marked the passing of the pioneering generation which crafted French prehistory into an internationally recognised branch of study, helping this young science to become a fullyfledged discipline in its own right.

\section{A pioneer of lithic technology research}

As both an experimental and speculative science, Prehistory lies at the interface of social and natural sciences and Jacques Tixier had the insight, energy and academic rigour to embrace this key area and devote himself to it. It was Tixier, that ardent and exacting researcher, who first dared to enter this field of study armed with a new investigative approach, enabling him to make great strides towards the understanding of human behaviour in prehistoric times. As an ethno-technologist, Jacques Tixier set out to study certain dialectical relationships in the interplay of Nature and 


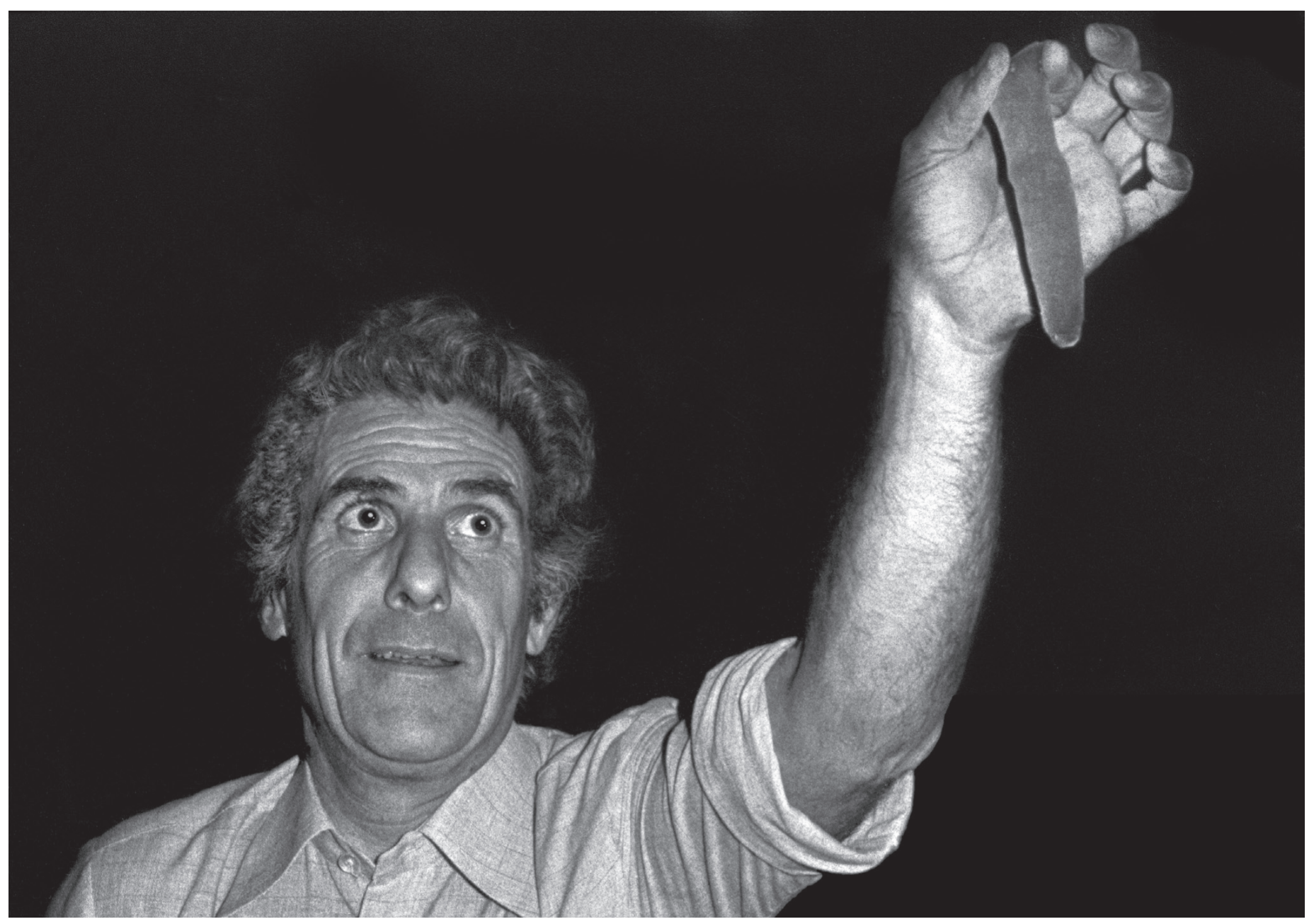

la gestion des ressources minérales propices à la production d'outils lithiques, les artefacts en pierre étant la catégorie de vestiges la plus souvent conservée sur les sites archéologiques. Cette démarche intellectuelle, entre Nature et Culture, illustrée d'une part par l'approche structurale de Claude LéviStrauss pour développer une anthropologie socio-culturelle, a été entamée par Jacques Tixier pour participer à une anthropologie matérielle sous l'angle original et pertinent de la technologie de la pierre taillée. Cette démarche novatrice peut être considérer comme une « anthropologie des techniques » en écho et dans le prolongement des travaux fondateurs de Marcel Mauss.

\section{Un maître tailleur, sur les traces d'Ishi, de Diman Balyo et d'autres}

S'appuyant en partie sur la notion de « chaîne opératoire » d'André Leroi-Gourhan et les premiers essais de François Bordes à la suite entre autres d'Hippolyte Müller, Henri Breuil et Léon Coutier, tout en approfondissant leur démarche respective, Jacques Tixier a donc accompli une véritable mutation du regard et des angles d'approches sur des vestiges répandus sur une grande partie de la planète. Ces déchets d'utilisation forment les seules « archives » conservées, sous forme d'objets manufacturés, de la part la plus longue de l'histoire de l'humanité. Issue d'un échange fécond avec des technologues américains pionniers travaillant sur les
Culture, in particular those dealing with the management of mineral resources suitable for the production of stone tools, stone artefacts representing the most common category of remains preserved on archaeological sites. This way of thinking, between Nature and Culture, exemplified by Claude Lévi-Strauss' structuralist approach in the development of socio-cultural anthropology, was initiated by Jacques Tixier to contribute to the anthropology of material culture using the original and pertinent angle of stone-age tool making as a starting point. This pioneering approach can be classed as an "anthropology of technology" in response to the seminal work of Marcel Mauss and as a continuation of it.

\section{A master of knapping technique - in the footsteps of Ishi, Diman Balyo and others}

Jacques Tixier began by basing himself in part on André Leroi-Gourhan's notion of the "chaîne opératoire" and the first trials of François Bordes following on from, inter alia, Hippolyte Müller, Henri Breuil and Léon Coutier. However, he went beyond what they had achieved and finished by bringing about a veritable volte-face in the way of looking at the remains spread out over a large part of the world and the angles from which they could be approached. These residues of use were the only "archives", in the form of manufactured objects, which had been preserved from the longest period in the history of mankind. His innovative approach is the result 
sociétés préhispaniques (en particulier Don E. Crabtree qui participa au premier Colloque de technologie lithique (non publié) aux Eyzies en novembre 1964, rencontre qui fut une révélation), son approche novatrice a influencé ethnologues et archéologues à travers le monde entier.

\section{Fondateur de l'approche technologique}

En pratiquant d'abord seul et en autodidacte la taille expérimentale du silex en Algérie dès les années 1950, Jacques Tixier a élaboré une nouvelle méthode d'analyse, dite de « technologie lithique » qui a permis de « faire parler » des centaines de milliers de vestiges préhistoriques, muets en apparence. Au-delà des outils taillés, du biface à la pointe de flèche, la technologie lithique permet en effet de reconstituer à partir des déchets de taille, du simple éclat au nucléus, les opérations intellectuelles et manuelles qui conduisent à la conception puis à la transformation d'une idée technique en outil fonctionnel. Aux marges des sciences cognitives et des « arts mécaniques », cette approche permet un dialogue immatériel avec les artisans préhistoriques, au point de rendre intelligible et lisible, depuis le Paléolithique inférieur jusqu'au Néolithique, des millénaires de productions humaines dont certaines peuvent s'avérer complexes. Ces examens reposent sur l'analyse du choix technique et économique des matières premières, dont le silex, le quartz et l'obsidienne (que Jacques Tixier affectionnait particulièrement), sont les plus connus car les plus sensibles aux ondes de fracturation.

\section{Un ouvrage fondamental : « Préhistoire de la Pierre taillée »}

Publiés entre 1980 et 1999, les cinq fascicules dela « Préhistoire de la Pierre taillée », rédigés et composés avec Marie-Louise Inizan, Michèle Reduron et Hélène Roche, forment le canon de la méthode d'analyse technologique de l'outillage préhistorique à l'échelle internationale. Dans un souci didactique le texte scientifique nécessairement très rigoureux de cet ouvrage fondateur est illustré avec de nombreuses planches pédagogiques. Une attention particulière est portée à l'harmonisation du vocabulaire spécialisé à employer. Dans cette perspective, sont exposées des définitions précises et détaillées des termes technologiques. Cette «bible » reconstituant la logique des premiers artisans de l'humanité propose un lexique spécifique. Traduit dans une dizaine de langues, de l'arabe au portugais, de l'anglais au russe, cet ouvrage fait désormais office de référent international.

\section{Un savant évergète}

Si l'Aquitaine, où Jacques Tixier nait en 1925, le sensibilise très tôt à la Préhistoire, c'est bien l'Algérie, où il arrive en 1947 pour y devenir instituteur à l'âge de 22 ans, qui lui fait pleinement découvrir, à fleur de désert, cette discipline à la croisée des sciences naturelles et humaines. Il côtoie au Maghreb plusieurs des principaux acteurs des recherches alors menées en Afrique du Nord, à commencer par Lionel Balout, professeur à la faculté d'Alger et conservateur du musée du Bardo. Entamant fouilles et études, c'est désormais en préhistorien que Jacques Tixier intègre le CNRS en 1955 puis of fruitful discussions with pioneering Americans working on the technologies of Pre-Hispanic societies (in particular Don E. Crabtree, who took part in the first Colloquium on Lithic Technology (not published) at Les Eyzies in November 1964, a meeting which proved to be a revelation); Tixier's approach has influenced ethnologists and archaeologists throughout the world.

\section{The founder of the technological approach}

While in Algeria in the 1950s, Jacques Tixier tried his hand at flint knapping which, teaching himself as he went along, led him to the development of a new method of analysis called "lithic technology". This made it possible to make hundreds of thousands of ostensibly mute prehistoric remains "break their silence". Going beyond the stone tools themselves, ranging from the handaxes to arrowheads, lithic technology enables scholars to reconstitute the intellectual and manual steps which led to the conception and then to the transformation of a technical idea into a functional tool simply on the basis of the left-over products of knapping, from simple flakes to cores. Operating on the borders of cognitive science and the "artes mechanicae" (in the sense proposed in the 12th century by H. de St Victor in his book Didascalicon), this approach opens the door to an ethereal dialogue with prehistoric craftsmen, to the extent that millennia of human achievements, some of which can be complex indeed, from the Lower Palaeolithic to the Neolithic, can be made intelligible and readable. These examinations take as their starting point an analysis of the technical and economic choice of the raw materials, of which flint, quartz and Tixier's particular favourite, obsidian, are the most well known, being the most responsive to shock waves produced as a result of knapping.

\section{The fondamental Book: Technology and Terminology of Knapped Stone}

The five volumes of the Technology and Terminology of Knapped Stone (French original title: Préhistoire de la Pierre taillée) published between 1980 and 1999 and produced jointly with Marie-Louise Inizan, Michèle Reduron and Hélène Roche constitute the internationally recognised reference work on tools produced and used in prehistoric times. The book is richly furnished with numerous explanatory illustrations to ease readers through the rigorously academic prose. The authors paid particular attention to harmonising the specialised technical terminology used, for which precise and detailed definitions are provided. This "Bible", which reconstitutes the thought processes of mankind's earliest craftsmen, uses a very specific set of terms. Translated into a dozen languages, ranging from Arabic to Portuguese and from English to Russian, this textbook is now the internationally acknowledged standard work on the subject.

\section{A scholarly benefactor}

Although it was in Aquitaine, where Jacques Tixier was born in 1925, that his interest in prehistory was first aroused, it was out in the desert in Algeria, where he arrived at the 
l'Institut de Paléontologie Humaine à Paris après 1961. Après avoir été Directeur des Antiquités préhistoriques de Lorraine, puis du Limousin, il fonde en 1980 entre Nanterre, Meudon et Valbonne un laboratoire du CNRS qui existe toujours - l'UMR 7705 « Préhistoire et technologie » et dont le champ d'études est mondial. Par son esprit fédérateur ses disciples, comme Catherine Perlès, Didier Binder, Jacques Pélegrin, Eric Boëda, Pierre-Jean Texier et tant d'autres, poursuivent du Japon au Brésil, de l'Afrique à la Grèce, une œuvre de défrichement et d'exhumation de ce qui peut tout aussi apparaître comme une forme de «langue » première et universelle : les gestes et les savoir-faire de la taille de la pierre. Jacques Tixier contre tout sectarisme rappelait souvent certains dangers inhérents à la pratique scientifique, à savoir ne pas tomber dans le piège des « ismes » : la technologie comme la typologie ne sont pas des fins en soi. Toutes démarches scientifiques employées en préhistoire doit veiller à ne pas tourner en rond sur ellemême et ne doivent pas oublier qu'elles ont pour but premier d'approfondir les connaissances sur la vie quotidienne des sociétés préhistoriques replacées dans leur environnement naturel.

\section{Un précurseur innovant et pédagogue}

Chez Jacques Tixier, le savant n'écrasait jamais l'homme. $\mathrm{Au}$ rayonnement national et international non content d'être un archéologue de terrain fouillant sur des aires géographiques et des périodes variées - Algérie, Liban, Qatar mais aussi et toujours le Sud-Ouest français chantiers sur lesquels des générations de chercheurs ont été formés, cet humaniste a été un pédagogue précoce, non seulement au sein des universités, mais aussi intervenant tôt au sein des classes primaires et secondaires, par des démonstrations spectaculaires de taille de la pierre et sous forme de films pédagogiques que l'on retrouve aujourd'hui diffusés sur le Web. Penseur libre et homme d'amitiés fidèles, Jacques Tixier était l'un de ces éminents chercheurs visionnaires qui ont révolutionné entièrement un champ disciplinaire, de manière discrète mais durable conjuguant enseignement théorique et pragmatique.

Au nom de nombreux chercheurs de tous les continents qui se joignent à nous pour témoigner leur reconnaissance, nous exprimons à la famille de Jacques Tixier, et en particulier à son affectueuse épouse Catie, toute notre compassion et leur adressons nos sincères condoléances.

La communauté scientifique française et étrangère perd un très grand préhistorien, un « passeur » de sciences altruiste, et ses compagnons de recherche perdent un précieux ami. En sa mémoire continuons nos investigations avec le même enthousiasme et exigence d'esprit qu'il aimait stimuler comme l'évoque une de ces dédicaces à l'encre verte (cet ancien enseignant n'aimait pas les annotations en rouge) :

«Esquille-toi, la Préhistoire te le rendra au plaisir de t’y plonger... ».

Demeure une œuvre scientifique féconde à laquelle il est bénéfique de se ressourcer. age of 22 to become a primary school teacher, that he fully embraced this discipline at the frontier between the natural and social sciences. In the Maghreb he frequented many of the men active in the research then being conducted in North Africa, starting with Lionel Balout, a professor at the university in Algiers and a curator at the Bardo museum. He began to study and conduct excavations, and it was in order to study prehistory that he went up to the National Centre for Scientific Research (CNRS) in 1955, followed by the Institute of Human Palaeontology in Paris from 1961. A stretch as Director of Prehistoric Antiquities in Lorraine was followed by a similar post in the Limousin before he founded a CNRS laboratory spread between the three sites of Nanterre, Meudon and Valbonne in 1980. This laboratory, Joint Research Unit (UMR) 7705 "Prehistory and Technology", is still in existence. Its field of interest is global. Faithful to his unifying approach, his disciples, such as Catherine Perlès, Didier Binder, Jacques Pélegrin, Eric Boëda, Pierre-Jean Texier and many others from Japan to Brazil, from Africa to Greece are busily engaged in doing the spadework for and uncovering what may very well come to seem like a form of primary and universal "language": the skills and knowhow involved in making stone tools. Opposed to all forms of dogmatism, Jacques Tixier frequently warned against some of the dangers inherent in academic practice, namely not falling into the "isms" trap: technology and typology are not ends in themselves. Whatever the academic approach used in prehistory, it was important to avoid focusing overmuch on procedure as such and forgetting that the primary purpose of studying prehistory was to increase the sum of knowledge of everyday life in prehistoric societies viewed in their natural environment.

\section{An innovative pioneer and teacher}

Jacques Tixier never allowed the scholar to overshadow the man. His influence in his field extended from France to the rest of the world. This humanist, who was more than a mere field archaeologist excavating sites in various regions covering different periods - in Algeria, the Lebanon or Qatar for example, but also, and particularly, sites in the French south west where generations of scholars had received their field training, was a teacher in advance of his time, not just at university level. He also reached out directly to primary and secondary schools, where he would give spectacular demonstrations of knapping techniques and also used educational films, which are now available on the web for all to see. A wide-ranging thinker and a loyal friend, Jacques Tixier was one of those eminent and visionary scholars who completely revolutionised their field of studies in a subtle and enduring manner with a combination of theoretical and practical instruction.

On behalf of the numerous scholars from all continents who join us in expressing their respect to the man and scholar, we extend our profound compassion and most sincere condolences to Jacques Tixier's family, and especially to his loving wife, Catie.

The academic community in France and abroad has lost a very great prehistorian. He was a selfless conveyor of 


\section{Bibliographie et webographie, bibliography and webography}

Essai de recensement des travaux de Jacques Tixier (état au 30 avril 2018), list of Jacques Tixier's works (status as of April $30,2018)$.

\section{Publications}

\section{0-1959}

Tixier, J. 1952. Un gisement préhistorique «in situ»au sud de BouSaâda. In: Actes du 2e Congrès Panafricain de Préhistoire, Alger, Arts et Métiers Graphiques (1955), p. 681-684.

Tixier, J. 1954. Le gisement préhistorique d'El-Hamel. Libyca 2: 79-120.

Tixier, J. 1955a. Un biface acheuléen dans le Sahel d'Alger. Bulletin de la Société Historique Naturelle d'Afrique du Nord 46: 277-279.

Tixier, J. 1955b. Les abris sous roche de Dakhlet es-Saâdane (commune mixte de Bou-Saâda); I, les industries en place de l'abri B. Libyca 3: $81-128$.

Balout L., Tixier, J. 1956a. L'Acheuléen de Ternifine. In: Comptes Rendus de la XVe session Congrès préhistorique de France, PoitiersAngoulême, p. 214-218.

Tixier, J. 1956b. Le hachereau dans l'Acheuléen nord-africain. Notes typologiques. In: Comptes Rendus du XVe sess. Congrès préhistorique de France, Poitiers-Angoulême, p. 914-923.

Tixier, J. 1958a. Les burins de Noailles de l'Abri André Ragout, Boisdu-Roc, Vilhonneur (Charente). Bulletin de la Société Préhistorique Française 55: 628-644. https://doi.org/10.3406/bspf.1958.3707

Tixier, J. 1958b. Les pièces pédonculées de l'Atérien. In: Ve Congrès de l'Union Internationale des Sciences Préhistoriques et Protohistoriques, 5e session, Hamburg, p. 813-817.

Tixier, J. 1959a. Les pièces pédonculées de l'Atérien. Libyca 6-7: 127-158.

Tixier, J. 1959b. Notes de typologie nord-africaine. I., Recherche des gestes techniques sur un burin exceptionnel. Libyca 6-7: 199-203.

Camps, G., Camps, H., Curtès, A., Curtès, E., Tixier, J. 1959c. Prise de date pour un gisement épipaléolithique et néolithique au Cap Chenoua (Algérie). Libyca 6-7: 289.

Tixier, J. 1959d. Les industries lithiques d'Aïn Fritissa (Maroc oriental). Bulletin D'Archéologie Marocaine 3: 107-244.

\section{0-1969}

Tixier, J. 1960a. Gravure rupestre de Bou-Saâda (Algérie). Bulletin de la Société Royale Belge d'études géologiques et archéologiques 17: 21-27. scientific knowledge and his academic colleagues have lost a dear friend. Let us commemorate his legacy by pursuing our work with the same enthusiasm and high standards of scholarship which he enjoyed encouraging, as shown by one of his dedications in green ink (this former teacher did not like using red ink for making annotations):

“Hammer away. Prehistory will reward your toil.”

He leaves a prolific body of work of enduring value that it is beneficial to re-read.

Tixier, J. 1960b. Examen en laboratoire de la «faucille $\mathrm{n}^{\circ} 2$ » de Columnata. Libyca 8: 253-258.

Tixier, J. 1962. Le «Tenéréen» de l'Adrar Bous III. In: Documents scientifiques Missions Berliet Ténéré-Tchad, Arts et Métiers Graphiques, Paris, p. 333-348.

Tixier, J. 1963. Typologie de l'Épipaléolithique du Maghreb. Mémoire $d u$ Centre de Recherche anthropologique, préhistorique et ethnographique 2, Arts et Métiers Graphiques, Alger-Paris, 211 p.

Tixier, J. 1965a. L'industrie capsienne d'Aïn Zannouch (Tunisie). In: XVIe session Congrès préhistorique de France, 1959, Monaco, p. 1027-1044.

Tixier, J. 1965b. Procédés d'analyse et questions de terminologie concernant l'étude des ensembles industriels du Paléolithique récent et de l'Épipaléolithique dans l'Afrique du Nord-Ouest. In: Background to evolution in Africa. Proceedings of a Symposium held at Burg Wartenstein Austria, July-August, 1965, University of Chicago Press, Chichago, p. 771-820.

Tixier, J. 1966a. Ouargla, découvertes préhistoriques. Compagnie Française des Pétroles (Algérie) Actualités 25: 4.

Tixier, J. 1966b. Fiches typologiques africaines, 1er cahier, fiches 1-32, Epipaléolithique du Maghreb, types 1-25. Muséum national d'histoire naturelle, Paris.

Tixier, J. 1966c. Têtes de flèches néolithiques appointées par la technique du «coup de burin». L'Anthropologie 70: 541-544.

Balout, L., Biberson, P., Tixier, J. 1967a. L'Acheuléen de Ternifine (Algérie), Gisement de l'Atlanthrope. L'Anthropologie 71: 217-238.

Tixier, J. 1967b. Fiches typologiques africaines, 3ème cahier, fiches 65-96, Pièces pédonculées atériennes du Maghreb et du Sahara, types 1-30. Muséum national d'histoire naturelle, Paris.

Méry, A., Tixier, J. 1967c. La station préhistorique d'Aïn-Chebli, region de Reggan (Sahara algérien). In: Actes du VIe Congrès Panafricain de Préhistoire, Dakar, p. 109-110.

Bayle, R., Tixier, J. 1967d. Le gisement kérémien de la Jumenterie de Chaouchaoua, Tiaret, Algérie. In: Actes du VIe Congrès Panafricain de Préhistoire, Dakar, p. 288-293.

Tixier, J. 1968a. Notes sur le Capsien typique. In: La préhistoire. Problèmes et tendances. Éditions du C.N.R.S., Paris, p. 439-451.

Tixier, J. 1968b. Informations archéologiques. Circonscriptions de Lorraine. Gallia Préhistoire 11: 343-352. https://doi.org/10.3406/ galip.1968.1326

Barrière, Cl., Daniel, R., Delporte, H., Escalon de Fonton, M., Parent, R., Roche, J., Rozoy, J-G., Tixier, J., Vignard, E. 1969. Épipaléolithique Mésolithique. Les microlithes géométriques. Bulletin de la Société Préhistorique Française 66: 355-366. https://doi.org/10.3406/ bspf.1969.4190 
1970-1979

Tixier, J. 1970a. L'abri sous roche de Ksar'Aqil. La campagne de fouilles 1969. Bulletin du Musée de Beyrouth 23: 173-191.

Tixier, J. 1970b) - Compte-rendu. de V. Gábori-Csánk: la station du Paléolithique moyen d'Erd.-Hongrie. Acta Archceologica Scientiarum Hungarica 22: 420-424.

Tixier, J. 1971. Les apports de la stratigraphie et de la typologie au problème des origines de l'homme moderne dans le Maghreb. In: Origine de l'Homme moderne (Écologie et Conservation, 3). U.N.E.S.C.O., Paris, p. 121-127.

Tixier, J. 1972. Obtention de lames par débitage «sous le pied». Compterendu des séances mensuelles de la Société Préhistorique Française 69: 134-139. https://doi.org/10.3406/bspf.1972.4365

Tixier, J. 1973a. Toolmaking. In: Cro-Magnon man, New-York, p. 83-91.

Tixier, J. 1973b. Note de typologie Nord-Africaine, II: une pointe «marocaine» inédite. In: Estudios dedicados al Profesor Dr. Luis Pericot, Universidad de Barcelona. Instituto de Arqueolgia y prehistoria publicaciones Eventuales 23, Barcelona, p. 47-49.

Tixier, J. 1973c. Informations archéologiques. Circonscription de Lorraine. Gallia Préhistoire 16: 439-461.

Tixier, J. 1974a. Microburins du Magdalénien V à la Faurélie II (Dordogne). L'Anthropologie 78: 189-196.

Tixier, J. 1974b. Glossary for the description of stone tools with special referance to the Épipalaeolithic of the Maghreb. Translation by M.H. Newcomer. Newsletter of lithic technology: special publication $1,36 \mathrm{p}$.

Tixier, J. 1974c. Fouille à Ksar'Aqil, Liban 1969-1974). Paléorient 2(1): 183-185. https://doi.org/10.3406/paleo.1974.4182

Tixier, J. 1974d. Poinçon décoré du Paléolithique supérieur à Ksar'Aqil (Liban). Paléorient 2(1): 187-192. https://doi.org/10.3406/ paleo.1974.4183

Tixier, J. 1975a. Les techniques de taille. Livret-guide exposition «Hommes de la Préhistoire», Bruxelles, p. 12-14.

Tixier, J. 1975b. Préhistoire en Moselle, fiche d'information, Association des amis de l'Archéologie mosellane, 1-2, p. 4-8.

Tixier, J. 1975c. Le site paléolithique de Ksar'Aqil. Compte-rendu des séances mensuelles de la Société Préhistorique Française 72(8): 226.

Balout, L., Chavaillon, J., Coppens, Y., Tixier, J. 1975d. L’Afrique, berceau de l'humanité? In: Une histoire de l'Afrique est-elle possible? Les Nouvelles Éditions africaines, Dakar, p. 51-85.

Tixier, J. 1975e. Informations archéologiques. Circonscription du Limousin. Gallia Préhistoire 18(2): 601-612.

Tixier, J. 1976a. French archaeological mission to Qatar. First campaign. C.N.R.S., R.C.P. 362, Paris. Ministry of Information. Doha, 27 p.

Tixier, J. 1976b. idem en langue arabe (idem in Arabic).

Tixier, J. 1976c. idem à 1972, en japonais (idem in Japan language). The Archaeological Journal 120: 11-16.

Tixier, J. avec la collab. de Marmier, F., Trécolle, G. 1976d. Le campement préhistorique de Bordj Mellala, Ouargla, Algérie. Cercle de Recherche. et d'Étude. Préhistorique., Paris, 61 p.

Tixier, J. 1976e. L'abri sous roche de la Faurélie II. Commune de Mauzens-Miremont. Livret-guide de l'excursion A4, IXe session du Congrès de l'Union Internationale des Sciences Préhistoriques et Protohistoriques, C.N.R.S., Paris, p. 113-116.

Mazière, G., Tixier, J. 1976f. Les civilisations du Paléolithique supérieur en Limousin. In: La Préhistoire française, IXe Congrès de l'Union Internationale des Sciences Préhistoriques et Protohistoriques, C.N.R.S., Paris, p. 1280-1296.

Mazière, G., Tixier, J. 1976g. Les civilisations de l'Épipaléolithique et du Mésolithique du Limousin. In: La Préhistoire française, IXe Congrès de l'Union Internationale des Sciences Préhistoriques et Protohistoriques, C.N.R.S., Paris, p. 1441-1446.

Tixier, J. 1976h. La Faurélie II. (In Les civilisations de l'Épipaléolithique en Périgord). In: La Préhistoire française, IXe Congrès de l'Union Internationale des Sciences Préhistoriques et Protohistoriques, C.N.R.S., Paris, p. 1427-1429.

Tixier, J., Inizan, M.-L., Roche, H. 1976i. Avantages d'un traitement thermique pour la taille des roches siliceuses. Quaternaria 19: $1-18$.

Tixier, J. 1976j. L'industrie lithique capsienne de l'Aïn Dokkara. Région de Tébessa, Algérie. Fouilles L. Balout. Libyca 24: 21-53.

Tixier, J. 1976k. Compte-rendu de: Camps-Fabrer H. Un gisement capsien de faciès sétifien, Medjez, II. El-Eulma (Algérie). Études d'Antiquités Africaines. (Éditions du C.N.R.S.). L’Anthropologie 80: 526-531.

Bayle des Hermens, R. de, Tixier, J. 1977a. Pointe pédonculée atérienne découverte à Bordj Chambi (Tunisie). L'Anthropologie 81: 631-634.

Tixier, J. 1977b. Informations archéologiques, circonscription du Limousin. Gallia Préhistoire 20: 493-516.

Tixier, J. et divers 1977c. L'Homme et son environnement pendant le Würm en Europe de l'Ouest. In: Union internationale pour l'étude $d u$ Quaternaire. Commission palecology of early man. Compte-rendu d'une réunion du sous-groupe de travail pléistocène supérieur, Ouest de l'Europe, organisée par J.-M. LE TENSORER, Université de Bordeaux III, Maison des Sciences de l'Homme 18-19 avril 1975), Bordeaux.

Tixier, J. 1978a. Bordj Mellala, un campement préhistorique au Sahara algérien. Universalia (Encyclopæedia Universalis), p. 191-193.

Tixier, J. 1978b. Bordj Mellala. Eine prähistorische Siedlung in der algerischen Wüste. Sahara 1000 jahre zwischen Weich und Wüste, Ausstellungskatalog, Köln, p. 177-180.

Tixier, J. 1978c. Archéologie de sauvetage en Afrique. In: Les recherches archéologiques dans les États d'Afrique au Sud du Sahara et à Madagascar, Ministère de la Coopération, p. 151-152.

Tixier, J. 1978d. La mission archéologique française à Qatar. Colloques internationaux du C.N.R.S., $n^{\circ}$ 580. L'archéologie de l'Iraq du début de l'époque néolithique à 333 avant notre ère. Perspectives et limites de l'interprétation anthropologique des documents, p. 207-208.

Inizan, M.-L., Tixier, J. 1978e. Outrepassage intentionnel sur pièces bifaciales néolithiques du Qatar (golfe arabo-persique). Quaternaria 20: 29-39.

Tixier, J. 1979a. Expérience de taille de flèches à tranchant transversal du type de l'Abri Jean-Cros. In: l'Abri Jean-Cros, essai d'approche d'un groupe humain du Néolithique ancien dans son environnement. Centre anthropologique des sociétés rurales, Toulouse, p. 127-129.

Marmier, F., Tixier, J., Trécolle, G. 1979b. Étude de l'industrie du gisement d'Hassi-Mouillah, région de Ouargla - Sahara algérien III: l'industrie lithique néolithique. Libyca 26-27: 81-115.

Tixier, J. 1979c. Expériences de taille. In: Préhistoire et technologie lithique, publications de l'Unité de Recherche Archéologique 28 (C.N.R.S.): cahier 1, Centre de Recherches Archéologiques du C.N.R.S., Journées du 11-13 juin 1979, p. 47-49.

Tixier, J. 1979d. Raccords et remontages. In: Préhistoire et technologie lithique, publications de l'Unité de Recherche Archéologique 28 (C.N.R.S.): cahier 1, Centre de Recherches Archéologiques du C.N.R.S., Journées du 11-13 juin 1979, p. 50-55.

1980-1989

Inizan, M.-L., Tixier, J. 1980a. Modifications possibles de la liste des types épipaléolithiques du Maghreb. In: Actes du 8e Congrès 
panafricain de Préhistoire et des Études du Quaternaire, Nairobi, 5 au 10 septembre 1977 , p. 25-26.

Rigaud, J.-Ph., Tixier, J. 1980b. Préhistoire, méthodologie. Encyclopcedia Universalis 13: 42-44.

Tixier, J. 1980c. Préhistoire, la taille expérimentale des roches dures. Encyclopcedia Universalis: 46-49.

Tixier, J., Inizan, M.-L., Roche, H. 1980d. Préhistoire de la Pierre Taillée, t. 1: terminologie et technologie. Cercle de Recherches et d'Études Préhistoriques, $120 \mathrm{p}$.

Tixier, J., Inizan, M.-L. 1981a. Ksar'Aqil, stratigraphie et ensembles lithiques dans le Paléolihique supérieur, fouilles 1971-1975. In: Colloques Internationaux du C.N.R.S. $N^{\circ} 598$ - Préhistoire du Levant. Maison de l'Orient. Lyon 10-14 juin 1980, p. 353-367.

Midant-Reynes, B., Tixier, J. 1981 b. Les gestes de l'artisan égyptien. La Recherche 120(12): 380-381.

Tixier, J. 1981c. Archaeology in Qatar. Total information 87: 34-36.

Tixier, J. 1982a. Nucléus-pendentif de Suse. Paléorient 8(2): 109-110. https://doi.org/10.3406/paleo.1982.4327

Chevalier, J., Inizan, M.-L., Tixier, J. 1982b. Une technique de perforation par percussion de perles en cornaline (Larsa, Iraq). Paléorient 8(2): 55-65. https://doi.org/10.3406/paleo.1982.4320

Tixier, J. 1982c. Techniques de débitage: osons ne plus affirmer. Studia Prchistorica Belgica 2: 13-22.

Roche, H., Tixier, J. 1982d. Les accidents de taille. Studia Prchistorica Belgica 2: 65-76.

Inizan, M.-L., Tixier, J. 1983a. Tell El'Oueili. Le matériel lithique. In: Larsa et Oueili, travaux de 1978-1981. Éd. recherches sur les civilisations, Paris, p. 163-175.

Inizan, M.-L., Tixier, J. 1983b. Idem en langue anglaise (idem in English language). Sumer 1-2: 62-65.

Aumassip, G., Marmier,F., Tixier, J., Trécolle, G.1983c.L'Épipaléolithique nord-saharien. Ouarglien ou Mellalien. Compagnie Française des Pétroles (Algérie).

Tixier, J. 1984a. Lames. In: Préhistoire de la pierre taillée. 2: Économie $d u$ débitage laminaire. Cercle de Recherches et d'Études Préhistoriques, Paris, p. 13-19.

Tixier, J. 1984b. Le débitage par pression. In: Préhistoire de la Pierre Taillée, t. 2: Économie du débitage laminaire. Cercle de Recherches et d'Études Préhistoriques, Paris, p. 57-70.

Tixier, J. 1984c. Escavaçoes no sitio de Ksar'Aqil, Libano. Resumo. In: Rivista de Pre-historia. Universidade de São Paulo. Institutto de Pré-historia. Edição comemorativa de cinqüentenario de Universidade de São Paulo, vol VI, p. 162.

Tixier, J. 1984d. Estructuras falsas, estructuras masaradas e estruturas fantasmas na região de Khor, Qatar, Golfo Arabico. Resumo. In: Rivista de Pre-historia. Universidade de São Paulo. Institutto de Pré-historia. Edição comemorativa de cinqüentenario de Universidade de São Paulo, vol. VI, p. 207.

Tixier, J. 1984e. Bordj Mellala - sitio superficial no Norte de Deserto de Saara, Argélia. Resumo. In: Rivista de Pre-historia. Universidade de São Paulo. Institutto de Pré-historia. Edição comemorativa de cinqüentenario de Universidade de São Paulo, p. 284.

Tixier, J. 1984f. Tecnologia litica: a contribuição das experiências de lascamento. Resumo. In: Rivista de Pre-historia. Universidade de São Paulo. Institutto de Pré-historia. Edição comemorativa de cinqüentenario de Universidade de São Paulo, p. 298.

Roche, H., Tixier, J. 1984g. Tecnologia litica: A questão dos acidentes de lascamento. Resumo. In: Rivista de Pre-historia. Universidade de São Paulo. Institutto de Pré-historia. Edição comemorativa de cinqüentenario de Universidade de São Paulo, p. 256.

Tixier, J. 1986. The prehistory of the Gulf: recent finds. In: Bahrain through the ages. KPI London, New York, Sydney and Henley.

Hublin, J.-J., Tillier, A.-M., Tixier, J. 1987a. L'humérus d'enfant moustérien (homo 4) du Jebel Irhoud (Maroc) dans son contexte archéologique. Bulletin et Mémoire de la Société d'Anthropologie de Paris, série XIV 4(2): 115-142. https://doi.org/10.3406/ bmsap.1987.1625

Briard, J., Tixier, J. 1987b. Approches technologiques des cultures préhistoriques. In: Images des Sciences de l'homme, Supplément au $n^{\circ} 67$ de La Recherche (C.N.R.S.), p. 85-88.

Mellars, P., Tixier, J. 1989. Radiocarbon-accelerator dating of Ksar'Aqil (Lebanon) and the chronology of the Upper Palaeolithic sequence in the Middle East. Antiquity 63(1): 761-768. https://doi. org/10.1017/S0003598X00076894

\section{0-1999}

Pélegrin, J., Tixier, J. 1990. Ve Symposium sur le silex, Section Technologie, Conclusions générales. In: Le silex de sa Genèse à l'Outil. Actes du Ve Colloque International sur le Silex, Cahiers du Quaternaire $n^{\circ}$ 17, p. 603-604.

Reduron, M., Tixier, J. 1991a. Et passez au pays des silex: rapporteznous des lames! In: 25 ans d'études technologiques en Préhistoire. XIe Rencontres Internationales d'Archéologie et d'Histoire d'Antibes. APDCA, Juan-les Pins, p. 235-243.

Tixier, J. 1991b. Cogitations non-conclusives. In: 25 ans d'études technologiques en Préhistoire. XIe Rencontres Internationales d'Archéologie et d'Histoire d'Antibes. APDCA, Juan-les Pins, p. 391-394.

Tillier, A.-M., Tixier, J. 1991c. Une molaire d'enfant aurignacien à Ksar'Aqil (Liban). Paléorient 17(1): 89-93. https://doi.org/10.3406/ paleo.1991.4541

Tixier, J. 1991d. Champ-Parel, Corbiac Vignoble 2 (CV2), Gallia Informations, Aquitaine, C.N.R.S., p. 8-10.

Tixier, J., Saint-Blanquat, H. de 1992a. Le Biface, silex taillé. In: Voyage en Préhistoire. Des objets font l'Histoire, Casterman, 45 p.

Inizan, M.-L., Roche, H., Tixier, J. 1992b. Technology of knapped stone. Préhistoire de la Pierre Taillée, t. 3, Cercle de Recherches et d'Études Préhistoriques, $127 \mathrm{p}$.

Tixier, J., Roe, D., Turq, A., Gibert, J., Martines, B., Arribas, A., Gibert, L., Gaete, R., Maillo, A., Iglesias, A. 1995a. Présence d'industries lithiques dans le Pléistocène inférieur de la région d'Orce (Grenade, Espagne): quel est l'état de la question? Compte-rendu Académie des Sciences de Paris série IIa 321: 71-78.

Inizan, M.-L., Reduron, M., Roche, H., Tixier, J. 1995b. Technologie de la Pierre Taillée, t. 4. Cercle de Recherches et d'Études Préhistoriques, Paris, 199 p.

Tixier, J. 1995c. La notion de chaîne de travail: chaîne opératoire de son application à l'élaboration/construction de la recherche. Exposé. In: Carrefour des Métiers: Les Dessinateurs en Archéologie. Centre de Recherches Archéologiques du C.N.R.S., p. 11.

Tixier, J. 1996. Technologie et typologie: dérives et sclérose. Quaternaria nova 6: 15-21.

Inizan, M.-L. Reduron, M., Roche, H., Tixier, J. 1998. Traduction en Japonais de (Japanese translation of): Technology of Knapped Stone, Préhistoire de la Pierre Taillée, t. 3, Cercle de Recherches et d'Études Préhistoriques, 1992, 147 p.

Inizan, -L., Reduron-Ballinger, M., Roche, H., Tixier, J. 1999a. Technology and terminology of knapped stone. Préhistoire de la Pierre Taillée, t. 5. Cercle de Recherches et d'Études Préhistoriques, $189 \mathrm{p}$.

Tixier, J. 1999b. Expérimentation, in Lucas, G. Production 
expérimentale de lamelles torses: approche préliminaire. Bulletin de la Société Préhistorique Française 96(2): 146. https://doi. org/10.3406/bspf.1999.10938

Tixier, J. et Turq, A. 1999c. Kombewa et alii. Paléo 11: 135-143. https:// doi.org/10.3406/pal.1999.1174

Tixier, J.1999d. Taille expérimentale des roches dures. In: Dictionnaire de la Préhistoire. Encyclopcedia Universalis, t. 13, p. 967-971.

Tixier, J. 1999e. Bordes François 1919-1981). In: Dictionnaire de la Préhistoire. Encyclopæedia Universalis, p. 228-230.

2000-2013

Tixier, J. 2000. Outils moustériens à bulbe «piqueté» (Retaïmia, Algérie). In: À la recherche de l'Homme préhistorique. E.R.A.U.L. 95, Liège, p. 125-130.

Inizan, M.-L., Tixier, J. 2001a. L'émergence des arts du feu: le traitement thermique des roches siliceuses. Paléorient 26(2): 2336. https://doi.org/10.3406/paleo.2000.4707

Tixier, J., Brugal, J.-Ph., Tillier, A.-M., Bružek, J., Hublin, J.-J. 2001b. Irhoud 5, un fragment d'os coxal non adulte des niveaux moustériens marocains. Société marocaine d'Archéologie et du Patrimoine 1: 149-153.

Bordes, J.-G., Tixier, J. 2002. Sur l'unité de l'Aurignacien ancien dans le Sud-Ouest de la France: la production de lames et de lamelles. Espacio, Tiempo y Forma, Revista de la Facultad de Geografia e Historia, Serie I 15: 175-194. https://doi.org/10.5944/ etfi.15.2002.4743

Hirth, G.H., Flenniken, J.J., Titmus, G.L., Tixier, J. 2003a. Alternative Techniques for Producing Mesoamerican Style Pressure Flaking Patterns on Obsidian Bifaces. In: Mesoamerican Lithic Technology. Experimentation and Interpretation. The University of Utah Press, Salt Lake City, p. 147-152.

Tixier, J. 2003b. Préface de Jacques Tixier. In: Le Capsien typique et le Capsien supérieur, evolution ou contemporanéité? Les données technologiques. Cambridge University Press, Oxford, p. 311.

Tixier, J. 2005a. l'Homme préhistorique, le silex et le feu. Présentation et résumé de: Inizan, M.-L. et Tixier, J. 2001a). Præhistoria 6: 47.

Tixier, J. 2005b. Modules et torsitude. Préface. In: Productions lamellaires attribuées à l'Aurignacien, chaînes opératoires et perspectives techno-culturelles. Actes du XIVe congrès de l'Union Internationale des Sciences Préhistoriques, Liège 2001. Collection ArchéoLogiques 1. Musée National d'Histoire et d'Art, Luxembourg, p. 19-21.

Tixier, J. 2012. A Method for the Study of Stone Tools. Guideline based on the Work of J. Tixier / Méthode pour l'étude des outillages lithiques. Notice sur les travaux scientifiques de J. Tixier. Collection ArchéoLogiques, 4. Musée National d'Histoire et d'Art - Centre National de Recherche Archéologique, Luxembourg, 197 p.

Mester, Zs. et Tixier, J. 2013. Pot à lames: the Neolithic Blade Deposit from Boldogkőváralja (Northeast Hungary), In: Moments in time. Prehistoric Studies 1. Ősrégészeti Társaság, Budapest, p. 173-185.

\section{Documents audiovisuels, Audiovisual references}

1967a. «Les plus vieux silex taillés», film Office Français des Techniques Modernes d'Éducation (Institut Pédagogique National) $8 \mathrm{~mm}$ couleur, 3 minutes.

1967b. «La taille des silex», film Office Français des Techniques Modernes d'Éducation (Institut Pédagogique National) $8 \mathrm{~mm}$ couleur, 3 minutes.

1968. «Outils préhistoriques. À la recherche des techniques de taille», réalisé par B. Mercier et J. Tixier, dans les studios de Office Français des Techniques Modernes d'Éducation (Institut Pédagogique National), 20 minutes, couleur, sonore, options: 16 ou $35 \mathrm{~mm}$, commentaire français ou anglais.

1973. Réalisation, en collaboration avec P. Guérin de deux Bibliothèques de Travail: B.T. n ${ }^{\circ} 854$ et 855 . La vie quotidienne des hommes préhistoriques. École Moderne. Composée chacune de: 1 disque double face 33 tours ( 2 fois $10 \mathrm{mn}$ ); 12 diapositives illustrant ce disque.

2016. « Jacques Tixier », 24 entretiens-documentaires filmés en 2015 au Musée national de Préhistoire. Interviews effectuées par Jean-Philippe Rigaud, Pierre-Jean Texier, Alain Turq. Série: Les Témoins de la Préhistoire. Pôle International de la Préhistoire, Les Eyzies-de-Tayac (F). À découvrir sur vimeo.com 